\title{
Severe health and social care issues among British migrants who retire to Spain
}

\author{
IRENE HARDILL*, JACQUI SPRADBERY $\dagger$, JUDY \\ ARNOLD-BOAKES** and MARIA LUISA MARRUGAT $+\dagger$
}

\begin{abstract}
In recent years, there has been a growth in academic interest in international retirement migration in Europe, particularly north-south retirement migration to destinations like Spain. In this paper we focus on those members of the British community who have lived in Spain for a considerable time and for whom familial, social and institutional ties with Britain are weak or disrupted. Age Concern España was established by members of the British community to provide information and services on healthcare, benefits and local services in Spain. Four indicative case studies of those requesting assistance and classified as being of 'serious need' are presented. They illustrate the ways in which happy and fulfilling lives in Spain were abruptly changed as the person's resources (bodily, economic, social and skills) for independent living diminished, and in which institutions and friendship networks played a key role in supporting life. The paper is the product of collaboration between researchers and practitioners in Spain and the UK, and brings together previous research with new qualitative case studies. Whilst policy-makers, practitioners and gerontologists have an increasing awareness of the needs of older migrants and the challenges they pose for public policy, particularly for health and social care systems in Spain, there have been little sustained analysis and cross-country debate.
\end{abstract}

$\boldsymbol{K E Y} \boldsymbol{W} O \boldsymbol{R D S}$ - retirement migration, European Union, health and wellbeing, Spain, United Kingdom.

\section{Introduction}

It is estimated that about one million British citizens own properties in Spain (Hellen 2002), and that $4^{0}$ per cent are over 50 years of age ${ }^{1}$ (King, Warnes and Williams 2000). Many have lived in Spain for over $3^{0}$ years.

* Graduate School, College of Business, Law and Social Sciences, Nottingham Trent University, UK.

$\dagger$ Age Concern England, London, UK.

** Age Concern España, Mallorca, Spain.

$\dagger \dagger$ Universitat Ramon Llull, Barcelona, Spain. 
In addition to the British community, there are sizeable communities of Scandinavian, French and German migrants (Casado-Díaz, Kaiser and Warnes 2004). Foreign homeowners outnumber Spanish home owners in nine of the I5 coastal areas of Spain (Norwood 2004). The figures must be interpreted cautiously, however, as they represent only those who are officially registered or who own property. O'Reilly (2000: I7) has emphasised that the members of the British community do not form a readily enumerated group. Some move back and forth, living part of the year in Spain and part in the United Kingdom (UK); some migrate temporarily, others permanently, and others return to live in the UK; altogether they are a nebulous group (see also Huber and O'Reilly 2004; Warnes et al. I999, 2004). In addition, the nature of the ties that bind these adults to the UK also vary - some have strong social networks in Britain, but for others they are weak or have dissipated (Huber and O'Reilly 2004). Previous research has tended to focus on the reasons for moving to Spain, and only a little has addressed the changing needs of the migrants as they age (Warnes et al. 1999: 725-35).

International retirement migration within Europe, or north-south retirement migration to destinations like Spain, have been conceptualised as a form of transmigration ${ }^{2}$ (Williams, King and Warnes 1997). To date, research on transnational living has largely ignored older adults (but see Gustafson 200I). In this paper we focus on members of the British community who have lived in Spain for a considerable time, whose familial ties and social networks with the UK are weak or have ossified, and for whom institutions and social networks within the British community in Spain, and some UK-based institutions (such as charities) play an important role in supporting life, especially at times of crisis.

The purpose of this paper is to identify and analyse the issues surrounding the growing number of older British people in Spain, especially those aged 75 or more years, who are experiencing increased vulnerability to ill health. The paper focuses on the role that institutions play in strengthening the social networks that support life as the migrants' bodily, economic, social and skills resources for independent living diminish. The research team was established by a UK charity, Age Concern England, which with its numerous independent local organisations is the largest UK voluntary movement working for and with older people. Its activities range from providing vital local services to influencing public opinion and government, and it publishes several information and fact sheets that cover the rights of older people (including an information sheet for people returning to the UK) (Age Concern England 2004a, 2004b).

Age Concern England supported members of the British community in Spain in the establishment of Age Concern España in 1994. It is now a 
national federation with five local organisations, and relies almost entirely on the unpaid work of members of the English-speaking community, except for one part-time employee and one charity-shop manager. The majority of the volunteers are British, but other nationals are involved, e.g. South Africans and New Zealanders. Age Concern España provides a LIFELINE service that supports people in difficult circumstances and provides information and advice to individuals, professionals and local groups. The local groups provide various direct services for older people, including home and hospital visiting, equipment loans and social activities. Since Age Concern España was established, the demand for its advice and services has steadily grown. ${ }^{3}$

A preliminary appraisal of the requests for information and advice made to Age Concern España in 2003 led to the formation of the research team and the more detailed analysis reported here. ${ }^{4}$ In the paper a multimethod and integrative approach is used to elucidate the lived reality of growing older in Spain. We draw on a literature review, an analysis of the records of requests made to Age Concern España for support, and consider several indicative cases of requests for support. The remainder of the paper has three parts. In the next section, the rights of migrants in the European Union (EU) migratory space are described, then the lived reality of growing older in Spain is presented, and the final section develops the conclusions.

\section{Migrations of European Union citizens to Spain}

\section{Rights of UK citizens and access to services in Spain}

Citizens of the member countries of the European Union (EU) are citizens of the EU and have the right to move and reside freely among the member states subject to certain conditions (Ackers and Dwyer 2004). The notion of European citizenship is built around an ideal of the citizen as a worker, and for economically-inactive groups, substantive rights (in particular to social welfare) are contingent on conditions set out in secondary European legislation (Dwyer 200I). Rights to access public-sector healthcare are an important component of social citizenship, particularly for people of state pension age whose need for treatment or long-term care may be relatively high. In the past, the EU has promoted cross-national health campaigns. Article 152 EC (ex Article 129) of the European Treaty contains a declaration that encourages co-operation between member states on general health matters. In reality, the rights and entitlements to public healthcare are determined by national laws and the systems operating in individual member states (Dwyer 200I: 315). 
Retired EU migrants have to be covered by sickness insurance of some kind. Some may purchase private health insurance, while those with a residence permit may make use of bilateral reciprocal arrangements between EU member states to access public healthcare - in these cases retired migrants are able to transfer their right to state healthcare, i.e. their public 'sickness insurance', to the host state. Any costs incurred in medical treatment abroad are then recoverable from their country of origin. These arrangements are complicated by various national laws and rulings which stipulate the categories of persons covered by public health-care and the costs, if any, to be incurred by the recipient. The right to access public healthcare in another EU host state does not imply a right to the same standard or level of entitlement as in the country of origin, but rather to the services normally enjoyed by a national in the host state (Dwyer 200 : 315).

If someone intends to reside in Spain for over go days per year, they are required to have a residence permit, but registration depends on evidence of adequate income. While a UK state pension can be paid in Spain, in many Spanish regions a UK state pension is regarded as insufficient income, which discourages registrations. As a resident, one is entitled to the same National Health Service care as Spanish nationals. This guarantees access to medical attention and assistance in hospitals, but not to posthospital assistance and care-at-home (which in Spain is scarce in comparison with northern European countries). The tradition of families caring for elderly relatives at home persists, but this arrangement is clearly problematic for retired migrants who have no relations living nearby (Ortiz, Ramon and Prats 2004). It is estimated that 42 per cent of older people in Spain live with their children, in contrast to only i 3 per cent in the UK (Jackson and Howe 2003).

The advantages of being officially registered, and therefore entitled to healthcare in Spain, brings a disadvantage for migrants who still spend long periods in the UK. Becoming an official resident in Spain means that one is entitled only to emergency healthcare in the UK, not to other National Health Service or local authority services including home-care. This can cause problems for those who return to the UK for short periods, and for those who permanently return at short notice. Many other Social Security benefits, including income-related payments such as Income Support, are not transferable to Spain. For others, such as Widows Benefits or Attendance Allowance (payable to people who are assessed as having a need for care), eligibility in Spain is dependent on certain conditions, e.g. whether one received the benefit before I June I992, when the regulations were revised. ${ }^{5}$

Many northern European retired migrants in Spain have private health insurance by which they can receive long-term health-care 
without officially registering as a resident. Some have found, however, that there are age-related increases in premiums, which as their income is usually static or declining causes financial stress. Funding for the national health services in Spain is generally allocated by a per capita formula, so the under-registration of migrants leads to under-funding in the regions with large concentrations of international retired migrants (Reverte-Cejudo and Sánchez-Bayle ı999; Morén-Alegret and Solana 2004). Further, the allocations do not take into account an area's demographic profile, so those with high concentrations of older people with high health and social care needs are not adequately compensated. Generally, there are very few publicly-managed care homes, and the places available accommodate only I.26 per cent of the older population (Sancho Castiello 2002). As noted above, most older people continue to be cared for in the home by members of the family, but care is being increasingly commodified and provided by migrant labour (Ortiz, Ramon and Prats 2004).

The British government does not currently accept that it has a responsibility to provide care for its citizens who are resident outside the $\mathrm{UK}$, even within the EU, and there is no immediate prospect of a change in this policy. On the other hand, numerous British migrants resident in Spain receive subsidies from British charities, such as the Royal Air Force Benevolent Fund. Age Concern España provides a casework service for many of these charities, which assesses the needs of the clients and liaises with the charities to access appropriate financial support for those in need. In addition, Spanish charitable organisations have developed several services that respond to the needs of the British community, e.g. the Spanish Red Cross has a 'telealarm' service with English-speaking operators. Many local voluntary organisations provide basic help to migrants, through home visiting, hospital visiting and interpretation services (Huber and O'Reilly 2004; O'Reilly 2000). A few also provide specialist advice services, which are used by individuals and by social services.

\section{The debate in Spain}

In Spain migrants are perceived as a source of economic gain, particularly in the property development, leisure and retail services sectors. Even frail older migrants make an economic contribution through job creation, e.g. home-helpers, and by promoting the provision of nursing homes (although there are concerns over the quality of these services). As many of the first wave of retired migrants from northern Europe are now reaching advanced old age and have increasing health and social care needs, the 
need to respond is increasingly recognised, particularly as it has become apparent that many do not want to return to their country of citizenship or origin (Betty and Cahill I998).

The situation of older northern European migrants who are becoming frail in Spain needs to be understood against the background of the country's political and economic development over the last 20 years (Ortiz, Ramon and Prats 2004). Compared with the UK, there is still a relatively low level of public and private personal social service provision for older people, and the Spanish are themselves frustrated with the slow pace of development and availability of publicly-funded services for older people (Tortosa and Granell 2002). Changes in Spanish society, particularly urbanisation, increases in female participation in the labour market, and greater spatial and social mobility of the population are stimulating the demand for formal services to support older people. Publicly-funded residential, day and domiciliary services, delivered by paid staff (and by volunteers) employed by private and non-governmental providers, are growing in Spain, but the availability of services is running behind demand in many areas.

The debate in Spain about English-speaking and northern European migrants is inextricably linked to the wider and more heated debate about recent trends in migration, especially legal and illegal migration from North Africa and Eastern Europe. It is also important for nonSpanish commentators to be aware of the political sensitivities associated with the ethnic, nationalistic, linguistic and cultural diversity of the various regional populations that for centuries have constituted 'Spain'. Given that several elements of the population of Spain are unhappy with the constitutional position and economic performance of their region, it is clearly difficult for the central or autonomous regional governments to dedicate considerable attention or resources to older foreign migrants.

\section{The lived experience of growing old in Spain}

In the remainder of the paper, we report on the lived reality of British migrants who are growing older in Spain. There are five local Age Concern España organisations, in Torrevieja, Estepona, Ibiza, Mallorca and Menorca. Without much advertisement of their services, Age Concern España receives about 12,00o enquiries a year. Many are requests for information about health-care, benefits, local services, and the 'Spanish system', but around one-in-eight notify a 'serious need' for additional income or support. The life stories and trajectories that lead up to these 
critical situations represent the many problems, losses and hardships that are experienced by an increasing number of older British retired migrants in Spain. We illustrate these problems through four actual case studies of people in 'serious need', all of whom were advised by the Age Concern España member of the research team. The names and specific details have been changed to protect their identity.

In-depth interviews structured by the individual's interests, commitments and unique personal circumstances-their 'constructed subjectivity' - were conducted with those directly involved in the four cases (McLaughlin I997: I3; van Manen I990). The intention was to provide insights into the lived experience of growing old in Spain, especially of those in need of acute support, and their wishes and expectations for life in Spain or the UK. Specifically we explored their access to support, as from nuclear and extended family members, friends and voluntary organisations. Many feminist researchers have adopted similar smallscale, qualitative strategies for their research, to break down hierarchical or professional objective knowledge (England I994). Such approaches allow the researcher to, 'incorporate difference and acknowledge the partiality and situatedness of our knowledge' (Staeheli and Lawson I994: 99; see also Hamel ig92).

\section{Common causes of difficulty for migrants in Spain}

An increasing number of British older people living in Spain are unable to support themselves, as a result of either health problems or lack of finance. Accurate data on the actual number is difficult to find, partly because of their under-registration as 'permanent residents' but also because of the scant research. In consequence, projections are impossible. The lack of systematic research evidence sustains false expectations about many aspects of daily life among those contemplating retirement to Spain, including the cost of living, the weather, housing conditions and the availability of support services. All of these can cause serious difficulties and compound the problems of illness or disability. Even basic facts are not appreciated, e.g. it is colder in many areas of Spain during the winter than many migrants realise (Age Concern España 2003). This leads to problems when migrants purchase housing with inadequate heating (Holbrook 2004: $\mathrm{I}-3$ and $\mathrm{I} 4 \mathrm{I}-2$ ). Misconceptions about entitlement to and the range of Spanish health services are commonly held, until a person needs treatment or continuing community health support, at which point the substantial differences between British and Spanish provision become clear (ibid. I32-40). Social and geographical isolation also cause problems for many older migrants. The 
benefits of living in an attractive, quiet and remote area may turn into serious disadvantages for an older person living alone who becomes frail, particularly if they do not speak Spanish (ibid. $9^{- \text {I I }}$ and 43-8). In many areas, public transport is often not available or infrequent, and if a partner who is the sole car driver in a household dies, those remaining can become seriously isolated (Harbert 1994). Spanish social workers and the British Consul have drawn attention to cases of older British people being found in their homes having died alone (British Consulate I995). This has occurred after discharge from hospital without after-care and following a relapse. We now examine through individual cases how happy and fulfilling lives in Spain have been abruptly changed as individual and household resources (bodily, economic, social, skills) for independent living diminished.

\section{George and Vera}

George and Vera moved to Spain in 1987 . Vera is 23 years younger than her husband and they decided to enjoy some retirement time together in a warmer climate; George suffered from arthritis and they thought the mild and dry winters would be beneficial. They had both worked for most of their lives and paid regular contributions into the UK National Insurance scheme. During the last six months of 2002, Vera's health deteriorated, and her liver failed at the end of the year. She required a cocktail of drugs to compensate, and doctors estimated her life expectancy in months. A few weeks before the kidney failure, other organs started to fail. The condition has affected her concentration and mobility. High toxin levels persist in her body causing inflammation of the brain (encephalopathy) and a comalike condition.

Vera then required 24-hour care, and George could no longer care for his wife at home. From hospital she was admitted to a nursing home where a shared room cost $€_{\mathrm{I}, \mathrm{O} 25}$ per month. Their income/savings were inadequate to cover this type of expenditure, and in search of advice the couple contacted Age Concern España (AC España). Although legally resident in Spain, no subsidies were available from local sources, nor was Vera eligible for subsidies from the UK. It is hoped that a British charity will give them a small 'nursing home grant' based on George's wartime service, but this is not anticipated to be more than $€_{9 \mathrm{I}}$ per month. Given the difference in their ages, it was not unreasonable for George to have anticipated that his wife would care for him in his advancing years. He now finds himself in the position of using most if not all of their savings to care for his wife, leaving little or no resources to provide for his future care. He wishes to remain in Spain because he regards the country as his home. 
Age Concern España is actively seeking other sources of charitable assistance for the couple.

\section{Frank and Foyce}

Although Frank and Joyce have lived in Spain for more than 20 years, they have no more than a few words of Spanish between them. Frank's health deteriorated suddenly and extensive medical tests diagnosed emphysema; they were carried out by the Spanish National Health Service under the reciprocal EU agreement. Before his final hospitalisation, Joyce found that she was no longer able to care for her husband without auxiliary nursing assistance. Unable to speak Spanish and not knowing what to do, Joyce sought advice from her local voluntary organisation, $A C$ España, which arranged through the municipal Social Services for the nursing assistance. When Frank was admitted to hospital, Joyce was unable to communicate with the doctors and therefore used volunteer interpreters. When Frank's condition stabilised, Joyce decided she was unable to care for him at home but had no idea how to find nursing home accommodation, with language again a barrier. AC España provided Joyce with the information she needed to make a considered choice of a nursing home, and persuaded the hospital consultant to keep Frank in hospital until the admission was arranged and he could be transferred directly. Since no nursing homes in the area had English-speaking staff, it took some time to find a nursing home with a vacancy and a member of staff who spoke a little English: it is over one-hour's drive from their home. The importance of speaking Spanish only became apparent to Joyce during this difficult time; previously she had been able to live happily in Spain without the ability.

Many retired migrants in Spain who are in good health and have no housing, financial or legal problems find that they can enjoy everyday life without needing to speak Spanish. But when a migrant needs health-care or personal support, especially 24-hour care, limited Spanish-language skills pose major problems. Finding a nursing home place is difficult in Spain even for the Spanish, but finding one where English is spoken is much more difficult. Communication is a proven factor in slowing down deterioration among people with various physical and mental health problems, and for people with dementia it is especially important that the carer is able to speak their own language. For some people, events such as bereavement or the onset of their own or a partner's serious illness or disability can quickly lead to a crisis. In these cases, the social support networks established in Spain may prove inadequate to the task of helping them to identify how to secure the support or care required. 
Fune

June worked throughout her adult life in a number of countries and had accumulated substantial assets, which she calculated would provide a comfortable retirement. As it turned out, however, her health deteriorated and she was diagnosed with severe osteoporosis. In the late ig9os, June (and I2 others) fell victim to a confidence trickster who persuaded expatriate older residents with no next-of-kin to give him Power of Attorney. This man placed June in a nursing home where she was neglected; he took over all her financial affairs and sold her apartment for a fraction of its true value to one of his relations. It was later accepted by the authorities that June was a prima facie victim of fraud. She lost all her papers and possessions.

When June's situation became known, she was moved to another nursing home and a grant towards the fees was sought from UK charitable sources. One was agreed but when added to the state pension, it pays only a fraction of the nursing-home charges. No other source of Spanish or British state funding is available to June. Her health is such that she is considered unfit to fly or to use any other means of transport. She is, therefore, unable to return to the UK where she would be eligible for assistance from a local authority. As no governmental source recognises June's position, she has become, in effect, the 'problem' of the owner of the nursing home who is subsidising her care.

The lack of accurate information and advice for people experiencing difficulties remains a recurrent problem. The positions of those who return to the UK (or other northern European countries) and of those who seek long-term support or care in Spain is widely misunderstood by individuals, voluntary organisations and local government departments. Individuals can experience a great deal of difficulty in establishing their rights and entitlements, and specifically in securing subsidised care or supplementary Social Security income. Managing a return to the UK can also present great difficulties. An increase in the quality and quantity of information and advice services would enable people to solve their problems more quickly and effectively.

June's case exemplified the particular difficulties of those whose careers were characterised by long periods of working abroad, including those who served in the armed forces - such backgrounds characterise many of $A C$ España's clients. For some, their attachment to, and social networks in, the UK are weak or non-existent: should they consider returning to the UK, they have no local ties and do not know to which local authority to apply for assistance. Some people in great difficulty who land at Heathrow Airport with no plans by default claim the assistance of the London 
Borough of Hounslow (Age Concern England, British Red Cross and Help the Aged I993). There is confusion about their rights: a clarification of Section 54 of the Nationality, Immigration and Asylum Act 2002 issued by the Department of Health (undated: I) states, 'councils are advised that European Economic Area ${ }^{6}$ adult nationals who work in the UK or used to work in the UK, and have the right to reside in the UK, should be able to access community-care and other social services on the same basis as UK nationals'.

\section{Freda}

Freda lived with her husband in Spain for more than 30 years before he died. Before her husband's death, she had been showing signs of dementia, which seemed to become more severe as she grieved for her husband. Friends made arrangements for Freda to be admitted to a Spanish nursing home, where although she was well cared for, the lack of communication in English and of mental stimulation worsened her condition, and there were other signs of failing physical health. She was transferred at the instigation of her friends to a nursing home where English was spoken, after which her mental health began to stabilise.

As the years went by, Freda's savings were eroded and, at the request of the nursing home owner, $A C$ España sought a charitable nursing home grant from the UK. All was well until the new EU regulations forced the closure of the nursing home - the owners were unable to pay for the necessary alterations. Freda (and two other women in similar financial positions and with similar medical conditions) could not afford alternative private-sector nursing-home care and were ineligible for care in publicsector nursing homes. All the other residents of the home were locals and were offered alternative places by the local authority, but the only course for the three English women was to return to the UK. Destitute, the three were repatriated and accepted by a local authority that placed them in appropriate care. In all cases, however, the trauma of the move brought about a rapid health deterioration and they died shortly thereafter.

Public housing and social services are controlled by local authorities in Great Britain (and by central government agencies in Northern Ireland). In most areas of the UK, there are waiting lists of people requiring social services care-assessments, which may fund places in residential care and nursing homes through the local authority 'community care' budget. Local authorities still allocate the budgets to people who have an established 'local connection', and are usually reluctant to take on people living elsewhere. This causes difficulty for people wanting to return to the UK who do not have a clearly established local connection. Freda was destitute 
and therefore claimed assistance on arrival, but although she was successful, the episode was unbearably traumatic.

The members of the four households in 'extreme need' had enjoyed several decades of happy and fulfilling retirement in Spain, but the onset of ill health or financial difficulty caused a radical change in the quality of their lived experience. The issues faced by the four households are neither new nor unique to older people living in Spain; indeed all four households would have faced considerable challenges if they had been resident in the UK. While the events are not particular to their status as migrants, the specificities of their situation in Spain added to their burdens. In two cases (George and Vera, and Freda), the onset of ill health meant for very different reasons that they had insufficient finances to cover the care-bills, and while one widow (Freda) was repatriated to the UK, sadly she died shortly afterwards.

In the case of Frank and Joyce, who had lived in Spain for 20 years, like many others they had lively happily without ever needing to expand their rudimentary Spanish vocabulary. But when one partner developed serious health problems, the inability to communicate with Spanish medical and social services staff presented severe problems and they were unable to deal with the crisis. The couple had lived in a largely British residential community, an 'expatriate bubble', a world within a world in southern Spain. June's case, not unique to Spain, was of a woman with no next-ofkin and living alone who became a victim of fraud. Her situation illustrates the human impact of the dispersion of family networks; the fact that she was living alone and in social isolation was exploited, and now she is in penury.

\section{Conclusion}

In this paper we have focused on those members of the British community who have lived in Spain for many years and for whom familial or social ties with Britain weakened or dissipated. Happy and fulfilling lives in Spain were abruptly changed as their resources (bodily, economic, social, skills) for independent living diminished, and institutions and friendship networks amongst the community played a key role in support. The presented household biographies have demonstrated the ways in which declining health (of the individual or of their partner) generates 'unmet needs' and results in a radical change in the quality of the lived experience in Spain. The issues described in this paper are timeless and many of the problems that older people face in Spain and in the UK are not specific to their status as migrants. Their damaging impacts are however 
unnecessarily prevalent because of the lack of understanding and communication about the needs, views and entitlements of older people, both in Spain and the UK. This makes the undesirable outcomes and hardship for older individuals unnecessarily widespread and exacerbated. The cases presented show that some members of the British community in Spain fall through a support gap, whereby they are no longer the responsibility of the UK welfare services, but also are not fully recognised in their new country of residence. The lack of understanding and communication acts as a barrier to the development of more effective and efficient policies. To improve the current situation, there is a need for more sustained research and analysis into the issues facing older migrants in Spain and other countries. Cross-country analysis will be vital in finding appropriate solutions in the countries of both origin and settlement.

\section{Acknowledgements}

This paper draws on research funded by Age Concern England and Age Concern España. We are grateful to the participants in this research and to Olwyn Ince for her research assistance. The views expressed here are those of the authors alone. Earlier versions of the paper were presented at the Vth European Congress of Gerontology, 5July 2003, Barcelona, and at the UK Regional Studies Association Conference on 'Europe at the Margins: EU Regional Policy, Peripherality and Rurality’, i6 April 2004, University of Angers, France.

\section{NOTES}

I And as such are 'older adults'. The diversity of the lived experience of British older adults is emphasised in the National Service Framework for Older People (Department of Health 200I), which identifies four distinct groups among those aged over 50 years: those entering old age; those who have completed their paid employment or childrearing; those in a transitional phase when aged in the late sixties and early seventies, and those aged 75 or more years with increasing vulnerability to ill health or declining mobility. The four categories span two to three generations and a vast range of experience, skills, quality of life and levels of wellbeing.

2 Trans-migrants are, 'those whose lived experiences transcend the boundaries of nation-states' (Bailey 200I : 414), and 'who develop and maintain multiple relationships - familial, economic, social, organizational, religious and political - that span those borders' (Basch et al. (1994: 7), cited in Bailey 200I : 4I4).

3 Age Concern England also commissioned a book to provide advice on living in Spain from Cyril Holbrook, who has lived in the country since I986 (Holbrook 2004). More information and much advice can be accessed directly through the Age Concern España website: www.acespaña.org

4 The research team comprises one employee of Age Concern England, a volunteer from Age Concern España and two social scientists, a geographer based in the UK and a gerontologist based in Spain. 
5 For full details of the UK social security benefits that a UK citizen resident abroad is entitled to, see http://www.dwp.gov.uk/lifeevent/penret/pr_visit_or_living_ abroad.asp

6 The European Economic Area (EEA) covers the countries that comprise the European Union (Austria, Belgium, Cyprus, Czech Republic, Denmark, Estonia, Finland, France, Germany, Gibraltar, Greece, Hungary, Ireland, Italy, Lithuania, Luxembourg, Malta, The Netherlands, Poland, Portugal, Slovakia, Slovenia, Spain, Sweden and the United Kingdom) plus Iceland, Liechtenstein and Norway.

\section{References}

Ackers, L. and Dwyer, P. 2004. Fixed laws, fluid lives: the citizenship status of postretirement migrants in the European Union. Ageing $\&$ Society, 24, 45 I-75.

Age Concern England 2004a. Retiring Abroad: Information for Older People Planning to Leave the UK. Available online at http://www.ace.org.uk/AgeConcern/media/ISIRetiring abroad.pdf [Accessed 6 September 2004].

Age Concern England 2004b. Information for Older People Moving Back to the UK. Available online at http://www.ace.org.uk/AgeConcern/media/IS2Informationforolderpeople movingbacktoUK.pdf [Accessed 6 September 2004].

Age Concern England, British Red Cross and Help the Aged 1993. Growing Old in Spain. Report of a symposium held in Alicante on 5/6 October 1992. Age Concern England, London.

Age Concern España 2003. Retiring to Spain. Age Concern España, Mallorca, Spain. Available online at http://www.acespana.org/acespana/files/retiring_to_spain.pdf [Accessed 6 September 2004].

Bailey, A. J. 200I. Turning transnational: notes on the theorisation of international migration. International Journal of Population Geography, 7, 413-28.

Basch, L., Glick Schiller, N. and Szanton Blanc, C. I994. Nations Unbound. Gordon and Breach, New York.

Betty, C. and Cahill, M. 1998. Consideraciones sociales y sanitarias sobre los inmigrantes britanicos mayores en España, en particular los de la Costa del Sol [The social and health circumstances of older British migrants in Spain, with particular reference to the Costa del Sol]. Migraciones, 3, 83-II5.

British Consulate in Alicante 1995. Care of the Elderly: The British Community on the Costa Blanca Alicante. British Consulate, Alicante, Spain.

Casado-Díaz, M. A., Kaiser, C. and Warnes, A. M. 2004. Northern European retired residents in nine southern European areas: characteristics, motivations and adjustment. Ageing E Society, 24, 3, 353-8I.

Department of Health 200I. The National Service Framework for Older People: Modern Standards and Service Models. Department of Health, London.

Department of Health. No date. Section 54 National Immigration and Asylum Act 2002 and Community Care and Other Social Services for Adults from EEA living in the UK: A Note of Clarification. Department of Health, London.

Dwyer, P. 200ı. Retired EU Migrants, healthcare rights and European social citizenship. Fournal of Social Welfare and Family Law, 23, 3, 31 I-27.

England, K. V. L. I994. Getting personal: reflexivity, positionality and feminist research. Professional Geographer, 46, I, 80-9.

Gustafson, P. 200I. Retirement migration and transnational lifestyles. Ageing E्F Society, 2 I, $37 \mathrm{I}-94$.

Hamel, J. 1992. The case study approach in sociology. Current Sociology, 40, I-7. 
Harbert, W. 1994. Migration of Older People: British People in Spain. Help the Aged, London.

Hellen, N. 2002. Tax break in the sun lures Britons to Tuscany. The Sunday Times, 25 August, I2.

Holbrook, C. 2004. Retiring to Spain: Everything You Need to Know. Age Concern, London.

Huber, A. and O'Reilly, K. 2004. The construction of Heimat under conditions of individualised modernity: Swiss and British elderly migrants in Spain. Ageing E̊ Society, 24, $3,327-5$ I.

Jackson, R. and Howe, N. 2003. The 2003 Aging Vulnerability Index: An Assessment of the Capacity of Twelve Developed Countries to Meet the Aging Challenge. Centre for Strategic and International Studies, Washington DC. Available online at www.csis.org/gai/ aging_index.pdf [Accessed 4 May 2004].

King, R., Warnes, A. M. and Williams, A. 2000. Sunset Lives: British Retirement Migration to the Mediterranean. Berg, Oxford.

McLaughlin J. 1997. Feminist relations with postmodernism: reflections on the positive aspects of involvement. Fournal of Gender Studies, 6, I, 5-I5.

Morén-Alegret, R. and Solana, M. 2004. Foreign immigration in Spanish rural areas and small towns: current situation and prospects. Finisterra: Revista Portuguesa de Geografia, 39, $77,2 \mathrm{I}-38$.

Norwood, G. 2004. The Brits are coming. The Sunday Times, 6 June, 4.

O'Reilly, K. 2000. The British on the Costa del Sol. Routledge, London.

Ortiz, A., Garcia Ramon, M. D. and Prats, M. 2004. Urban planning and women's sense of place in a historical neighbourhood of Barcelona. In Cortesi, G., Cristaldi, F. and Droogleever Fortuijn, J. (eds), Gendered Cities: Identities, Activities and Networks: A Life Course Approach. Societa Geografica Italiana, Rome, I I-24.

Reverte-Cejudo, D. and Sánchez-Bayle, M. I999. Devolving health services to Spain’s autonomous regions. British Medical fournal, 318, 1204-5.

Sancho Castiello, M. 2002. Ageing in Spain. Institute of Migration and Social Services (IMSERSO), Madrid.

Staeheli, L. A. and Lawson, V. A. I994. A discussion of women in the field: the politics of feminist fieldwork. Professional Geographer, 46, I, 96-io2.

Tortosa M. A. and Granell, R. 2002. Nursing home vouchers in Spain: the Valencia experience. Ageing \&O Society, 22, 6, 669-87.

Van Manen, M. 1990. Researching Lived Experience: Human Science for an Action Sensitive Pedagogy. State University of New York Press, New York.

Warnes, A. M., King, R., Williams, A. M. and Patterson, G. I999. The well-being of British expatriate retirees in southern Europe. Ageing \& Society 19, 717-40.

Warnes, A. M., Friedrich, K., Kellaher, L. and Torres, S. 2004. The diversity and welfare of older migrants in Europe. Ageing \& Society, 24, 3, 307-26.

Williams, A., King, R. and Warnes, A. M. I997. A place in the sun: international retirement migration from northern to southern Europe. European Urban and Regional Studies, $\mathbf{4}$, 2, II $5-34$.

Address for correspondence:

Accepted 3 May 2005

Irene Hardill, The Graduate School, College of Business, Law and Social Sciences, Nottingham Trent University, Burton Street, Nottingham NGi ${ }_{4} \mathrm{BU}, \mathrm{UK}$.

$$
\text { e-mail: Irene.Hardill@ntu.ac.uk }
$$

